\title{
THE IMPLEMENTATION OF MARKETING 3.0 TO MSMES IN SURABAYA CITY
}

\author{
Metta Padmalia \& Dewi M. Immanuel \\ Fakultas Manajemen dan Bisnis, Universitas Ciputra Surabaya
}

\begin{abstract}
The role of Micro, Small and Medium Enterprises (SMEs) is very important as an economic force to countries, especially developing countries like Indonesia. However, the role of the government is still ineffective to support SMEs. As a result, they cannot grow optimally. As one of the economic forces, the role of SMEs is worth considering when ASEAN Economic Community (AEC) begins by the end of 2015. This study aims to investigate how SMEs' product brands were able to support the economics of the country. Using descriptive qualitative, this study collected the primary data by interviewing five SMEs assisted by Diskoperindag of Surabaya city. This research found that Entrepreneurial Strategy Marketing 3.0 through brand development models 3i (image, identity, integrity) fit the needs of SMEs assisted in Surabaya so that they are able to develop their businesses to face the AEC.
\end{abstract}

Keywords: SMEs (small and medium enterprises), marketing 3.0, model 3i, AEC (ASEAN Economic Community), entrepreneurial strategy

\section{INTRODUCTION}

The ASEAN Economic Community (MEA) is an agreement made by ASEAN countries to establish a new unlimited market condition within the field of economic. MEA is a term adapted from the ASEAN Economic Community (AEC) which causes free goods and services to flow from one country to another without any import duty (Tyas \& Safitri, 2014). The main concept of MEA is to make ASEAN countries as single market and unity of production base where free flow of goods, services, factors of production, investment, and capital, and the elimination of tariff take place for trade among ASEAN countries. The purpose of this MEA cooperation is expected to help reduce poverty and economic disparity among its member countries. Indonesia, according to Kartajaya et al., (2015), has a high power and potential in ASEAN which is seen from the total

\footnotetext{
*Corresponding Author.

e-mail: metta.padmalia@ciputra.ac.id
}

population. Indonesia whose GDP has reached 36.04 percent reached 38.61 percent of the total ASEAN and. However, MEA can also be a challenge for Indonesia. If Indonesia is not ready, local players with limited capital will be 'run over' by foreign players (Kartajaya et al., 2015).

The existence of MSMEs is extremely important for they proved to be able to survive and become the driving wheel of the economy, especially after the economic crisis. On the other hand, MSMEs also face many problems, namely limited working capital, low human resources, and the lack of mastery of science and technology (Sudaryanto and Hanim, 2002).

According to the data from BPS Online, SMEs in Indonesia experienced significant growth in 2013-2015 (see Table 1). The increasing number of business units makes them support force for the country's economy in the current MEA era. However, the competitive advantage of MSME products is still a big challenge that needs to be improved. 
Metta Padmalia \& Dewi M. Immanuel / The Implementation of Marketing 3.0 to MSMEs in Surabaya City / JEE, Vol. 7, No. 1, March 2018, pp. 1-10

Table 1 Number of UMKM 2013-2015

\begin{tabular}{|l|r|r|r|r|r|r|}
\hline \multirow{2}{*}{ Province } & \multicolumn{2}{|c|}{2013} & \multicolumn{2}{c|}{2014} & \multicolumn{2}{c|}{2015} \\
\cline { 2 - 7 } & \multicolumn{1}{|c|}{ Micro } & \multicolumn{1}{c|}{ Small } & \multicolumn{1}{c|}{ Micro } & \multicolumn{1}{c|}{ Small } & \multicolumn{1}{c|}{ Micro } & \multicolumn{1}{c|}{ Small } \\
\hline Indonesia & $2,887,015$ & 531,351 & $3,220,563$ & 284,501 & $3,385,851$ & 283,022 \\
\hline East Java & 539,320 & 89,786 & 608,774 & 39,932 & 771,185 & 49,659 \\
\hline
\end{tabular}

Source: BPS

According Ganie (2012), the government is planning to empower SMEs (Micro Small and Medium Enterprises) by providing training and business capital loans. Ganie (2012) also mentions that the presence of MEA has the potential to encourage SMEs to grow and develop because it is in line with the increasing breadth of access to markets and sources of financing. As one of the backbone of the economy in developing countries including Indonesia (Hadiyati, 2015), SMEs need to be supported by either training or ease of lending business capital (Swa Online Magazine, 2014).

To improve the competitiveness of SMEs, the government through Diskoperindag (Department of Trade Industry Cooperation) has conducted various coaching activities such as training, guidance through seminars, and knowledge of the types of machines. These activities are expected to help SMEs in production, and assist their marketing and product promotion through exhibitions and cooperation with other business units outside UMKM.

The marketing of MSMEs should be developed in contrast to larger scale enterprise marketing (Hills et al., 2008). Pandeya (2010) mentions that marketing for small and medium enterprises need to focus on the use of informal intuition in decision making.

The current marketing concept has entered the era of marketing 3.0 whose focus is on values-driven marketing. Changes in consumer behavior and attitudes in the marketing
3.0 era are the media to influence marketing practices. This is due to the presence of three major forces, the new wave technology in the form of social media (twitter, Facebook Wikipedia, and the like), globalization, and the emergence of creative society (Kotler et al., 2010). Kotler et al., (2010) also stressed that the company must see the customer as a multidimensional human consisting of mind, heart, and spirit. Kotler introduced Model 3i consisting the harmonization of brand identity, brand integrity, and brand image. This model explains that the company's marketing must be able to define its unique identity and reinforce it with authentic integrity to build a strong image.

Based on the description of these phenomena, it is necessary to do research on entrepreneurial strategy marketing 3.0 to SMEs in Surabaya. Based on the background, the research problems are formulated as follows:

- What is the role of Diskoperindag in supporting the development of MSMEs in the era of MEA?

- How is entrepreneurial strategy Marketing 3.0 model $3 \mathrm{i}$ implemented by MSMEs in facing MEA?

This research is expected to provide significant benefits:

a. It is expected to provide scientific contributions, thoughts, and ideas to understand the entrepreneurial marketing strategy in the scope of $3 \mathrm{i}$ model of Marketing 3.0. 
b. It is expected to sharpen the experience and knowledge of SMEs in the field of entrepreneurial marketing strategy, especially regarding the 3i model of Marketing 3.0.

c. It is expected to propose marketing strategy for UMKM actors to face MEA in order to compete in the global markets.

\section{LITERATURE REVIEW}

Entrepreneurial marketing, Marketing 3.0, and Challenges and Opportunities MEA for MSMEs are the concepts used to base the problem formulation and research objectives.

\section{Entrepreneurial Marketing}

Entrepreneurial marketing combines two different studies of science which are used to describe a company's process of pursuing opportunities under conditions of market uncertainty (Becherer et al., 2006). The terminology of entrepreneurial marketing is defined by Morris et al., (2002) as proactive identification and exploitation of opportunities in acquiring customers through innovative approaches by adding value to a business.

The concept of entrepreneurial marketing, according to Ionita (2012), emerged as the response to several studies showing inconsistency between traditional marketing theory and marketing practices conducted by small micro business actors (UMKM) or on business startup actors. These conditions illustrate that the traditional marketing concept originally developed for large companies was directly not applicable to MSMEs without any adjustment (Stokes, 2000). Morish et al., (2010) define such entrepreneurial approach as an idea and mindset for actions that are driven by opportunities or activities to seek opportunities.
The concept of entrepreneurial marketing when compared to traditional marketing is more associated with more opportunity-driven marketing practices (Hills et al., 2008) and this concept integrates marketing with innovation, centered on the principles of entrepreneurship (Morish et al., 2010). Businesspeople are required to innovate in the application of entrepreneurial marketing in order to increase demand. Pandeya in 2010 believes that business people are quick to respond to market conditions and meet the demands of its customers, referred to as entrepreneurial marketers.

\section{Marketing 3.0}

The current marketing is not only translated in terms of positioning, differentiation and brand spelled out in brand identity, brand integrity, and good brand image. However, according to Kotler et al., (2010), companies need to show the values (spiritual) in marketing. Those values are believed to not only boost profits but also ensure sustainability and strengthening of brand character, while forming unparalleled differentiation. Era Marketing 3.0 one can be seen when the company is not only to market products with functional benefits and emotional benefits but also to highlight the spiritual benefits.

Marketing studies are transformed from Marketing 1.0 to Marketing 2.0 to the present leading to Marketing 3.0. Marketing 1.0 relies on rational intelligence. Good product goes hand in hand with reasonable price. Consumers choose products based on the high price offered by the manufacturer. The level of marketing is intellectual by using powerful tools such as marketing mix, branding, positioning, etc. so that consumers are very easy to move (Kotler et al., 2010). 
Metta Padmalia \& Dewi M. Immanuel / The Implementation of Marketing 3.0 to MSMEs in Surabaya City / JEE, Vol. 7, No. 1, March 2018, pp. 1-10

Marketing 2.0 is characterized by emotional marketing that relies on emotional intelligence. The tagline of Marketing 2.0 is "touch the hearts of customers". The product offered may be more expensive than other company's products, but the product will still be chosen by the consumer because many already have an emotional bond with the product. Marketing 2.0 is widespread and buzzword marketing is widely used, such as: customer relationship management, experiential and emotional marketing (Kotler et al., 2010).

Marketing 3.0 is growing at this time based on the spiritual intelligence. Marketing in this concept shifts toward the spiritual that is believed to not only boost profit, but also ensure sustainability and strengthening the character of the brand, and form a truly authentic distinction that is difficult to match. The important thing in Marketing 3.0 is that marketers have to aim mind and spirit simultaneously to reach the hearts of consumers. The Marketing 3.0 concept sees the customer as a multidimensional human consisting of mind, heart, and spirit. Kotler et al., (2010) introduces Model 3i (identity, integrity, and image), in which the company must be able to define its unique identity and reinforce it with authentic integrity to build a strong image (see Figure 2).

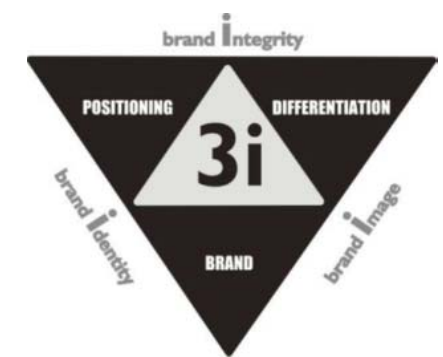

Figure 2 Model 3i from Marketing 3.0

(Source: Kotler et al., 2010).

Figure 2 above illustrates that according to Kotler et al., (2010), in the era of Marketing
3.0, marketing must be redefined as a triangle of brand, positioning, and differentiation. Brand does not mean anything if only articulate its positioning. Brands may have a clear identity in the minds of consumers, but not necessarily a good identity. Kotler and Keller (2007) revealed that positioning is a clear statement to awaken consumers to be careful of unauthentic brands. The relationship with triangle model $3 \mathrm{i}$ is that positioning will not be complete without differentiation. Differentiation is often seen as the core of a brand that reflects the true brand integrity, so differentiation is strong evidence that the brand manages to deliver on its promise. Brand integrity revolves around being credible, keeping promises, and creating consumer confidence in the brand. The existence of an identity reinforced by brand integrity will produce a good brand image in the mind of the customer (Kotler et al., 2010)

\section{UMKM - Challenges and Opportunities in Fac- ing MEA}

\section{Criteria of Micro Small and Medium Enter- prises (MSMEs)}

a. The criteria of Micro, Small and Medium Enterprises (MSMEs) according to Law Number 20 Year 2008 based on the amount of assets and turnover owned by a business.

Table 2 The Criteria of MSMEs

\begin{tabular}{|c|c|c|c|}
\hline \multirow{2}{*}{ No. } & \multirow{2}{*}{ Category } & \multicolumn{2}{|c|}{ Criteria } \\
\hline & & Asset & Omzet \\
\hline 1 & Micro & $\max 50$ millions & Max 300 millions \\
\hline 2 & Small & $>50$ million- 500 million & $>300$ million $-2,5$ billion \\
\hline 3 & Medium & $>500$ million -10 billion & $>2,5$ billion -50 billion \\
\hline
\end{tabular}

Source: Ministry of Cooperatives and Small and Medium Enterprises, 2012

b. The criteria of Small and Medium Enterprises Based on Development, according to 
Rahmana (2008), based on the development of MSMEs can be grouped into some criteria:

1) Livelihood Activities: a Small and Medium Business that is used as a job opportunity to earn a living, which is more commonly known as the informal sector. Examples are street vendors.

2) Micro Enterprise: a Small and Medium Enterprises that has a craftsmanship but has no entrepreneurial character.

3) Small Dynamic Enterprise: a Small and Medium Enterprises that already has an entrepreneurial spirit and is able to accept subcontract and export jobs

4) Fast Moving Enterprise: Small Medium Enterprises that already have entrepreneurial spirit and will make the transformation into a big business (UB).

Suryana (2013) has formulated global challenges facing entrepreneurs such as global competition, population growth, unemployment, social responsibility, labor diversity, ethics, technological progress, science and lifestyle. Tyas and Safitri (2014) say if the company is not adaptive to the increasingly heavy global competitions the company will face the threat of loss of the resources. MEA era can serve as an opportunity for Indonesia because of the vastness of the market that penetrated to ASEAN countries. However, if not balanced with the readiness of government, the business and professionals can be difficult issues to face.

According to Tambunan (2012), the level of competitiveness of a country in the international trade arena is basically determined by comparative advantage factor (competitive advantage) and competitive advantage factor. The factor of comparative advantage can be consid- ered as a natural factor; meanwhile, the factor of competitive advantage is considered as a factor acquired or can be developed/created. In addition to these two factors, the competitiveness of a country is actually also influenced by Sustainable Competitive Advantage (SCA) or the sustained competitive advantage. They are needed to face the level of increasingly tight global competition or Hyper Competitive especially with the MEA.

The addition and guidance of MSME sector are being intensively conducted nowadays to face MEA. The online BPS (2015) shows that the contribution of MSME to Indonesia's GDP in 2012 is $9.90 \%$ with the growth of its workforce of $5.83 \%$. They always increase from year to year. MSMEs also contribute to the addition of foreign exchange in the form of export earnings, amounting to 27,700 billion and create a role of $4.86 \%$ of total exports (Nagel, 2012). However, the contribution of SMEs to the country's foreign exchange is much smaller than the contribution of large businesses. In fact, the former tended to increase from year to year. Thus, UMKM should be more fostered and developed.

\section{RESEARCH METHODS}

This study used a qualitative approach. According to Cooper (2006), this research design is known a series of data interpretation techniques to explain, transform, translate, and explain the meaning, of a social event that occurs less naturally.

The procedures for conducting this research begins by focusing on the assessment of the sources, the collection of data through their stories, the reporting of their experiences, and the chronological arrangement of the meaning 
Metta Padmalia \& Dewi M. Immanuel / The Implementation of Marketing 3.0 to MSMEs in Surabaya City /

JEE, Vol. 7, No. 1, March 2018, pp. 1-10

of the experience. The objective of this research is to describe the process of how the informant describes the understanding of MEA, the role of Diskoperindag in the development of UMKM, and the understanding of Model 3i Marketing 3.0 on the marketing of its business. The study involved five owners of SMEs in the city of Surabaya who have got supports from Diskoperindag Surabaya.

\section{Data Collection Method}

The data was collected by conducting semistructured in-depth interviews, obtained through interviews of MSME owners. This study used interviews with open-ended questions. According to Reja et al., (2003), open-ended questions were questions requiring the respondents to give in depth descriptions and explanations.

\section{Validity}

To determine the validity of the data required some techniques. Triangulation, according to Denzin in Moleong (2015), is divided into four kinds of triangulation of sources, methods, investigators, and theory. In this study, the triangulation of sources was intended to ensure the validity of research data. Patton in Moleong (2015) describes source triangulation as a process of comparing and checking the degree of confidence of information gained through different times and tools in qualitative research. This can be achieved by (1) comparing the observed data with the interview data, (2) comparing the results of the interview with the contents of a related document.

Description of data of interview result which has been tested its validity as follows: (1) marketing strategy that has been applied, (2) current business development, (3) business constraint faced, (4) development effort of trademark, (5) ) understanding and application of brand identity, (6) understanding and application of brand image, (7) understanding and application of brand integrity.

\section{Data analysis method}

Data analysis was performed using Miles and Huberman (1984) model, including data reduction, data presentation, and conclusion. The steps to analyze the results of this study were as follows:

1. Reduce data by selecting data in accordance with the distribution strategy.

2. Test the validity of data through triangulation method of data source.

3. Systematic presentation of data in the form of summary tables and narrative texts.

4. Formulate conclusions and suggestions from the results of research.

\section{RESULTS AND DISCUSSION}

The data obtained from the interviews to the informants were identified and analyzed based on each domain set at the beginning. Here is a summary of the responses from the five informants to the questions given (Table 3).

Based on the results of the interview summary in Table 3, it can be seen that all informants who owned UMKM business under the guidance of Diskoperindag Kota Surabaya were all in the form of handicraft (batik, food and handicraft). In general, the five informants considered that their business have indergone significant grwoth. It was due to the role and support of Diskoperindag Kota Surabaya such as trainings for MSME owners. 
Table 3

Summary of Interviews with Five UMKMs Built by Diskoperindag

\begin{tabular}{|c|c|c|}
\hline $\begin{array}{l}\text { Name of MSME \& } \\
\text { Identity }\end{array}$ & Questions & Summary of informant statement \\
\hline \multirow{11}{*}{$\begin{array}{l}\text { UD. ASIH } \\
\text { - Owner: Sumiarni } \\
\text { - Merchandise type: } \\
\text { Cake Pia } \\
\text { - Long standing: } 10 \mathrm{yrs} \\
\text { - Business address: Jl. } \\
\text { Pandegiling 5/7, Sby } \\
\text { - Number of employees: } \\
3 \text { persons } \\
\text { - Turnover/month } \\
\text { range: Rp. } 4 \text { millions } \\
\text { - Range of net } \\
\text { profit/month: Rp. } 1.5 \\
\text { millions }\end{array}$} & $\begin{array}{l}\text { Marketing strategy that has been } \\
\text { applied }\end{array}$ & $\begin{array}{l}\text { - Consignment } \\
\text { - Exhibition } \\
\text { - Direct selling }\end{array}$ \\
\hline & $\begin{array}{l}\text { The current business develop- } \\
\text { ment }\end{array}$ & $\begin{array}{l}\text { The business is growing quite well, in the stage } \\
\text { of increasing turnover }\end{array}$ \\
\hline & Business constraints faced & Constraints in the management of PIRT \\
\hline & $\begin{array}{l}\text { The role of Diskoperindag } \\
\text { Surabaya }\end{array}$ & $\begin{array}{l}\text { Help market promotion } \\
\text { Logo }\end{array}$ \\
\hline & Trademark development effort & Maintain quality and taste \\
\hline & & $\begin{array}{l}\text { The use of unique names to keep customers in } \\
\text { mind }\end{array}$ \\
\hline & $\begin{array}{l}\text { Understanding and implement- } \\
\text { ing brand identity }\end{array}$ & Typical logo and pia flavor. \\
\hline & $\begin{array}{l}\text { Understanding and } \\
\text { implementing brand image }\end{array}$ & $\begin{array}{l}\text { MEA causes goods from abroad to be free entry } \\
\text { to Indonesia }\end{array}$ \\
\hline & $\begin{array}{l}\text { Understanding and implement- } \\
\text { ing brand identity }\end{array}$ & $\begin{array}{l}\text { MEA as a challenge (must always fix products } \\
\text { sold) as well as opportunities (possibly pene- } \\
\text { trated into the global market) }\end{array}$ \\
\hline & $\begin{array}{l}\text { Understanding of the MEA } \\
\text { MEA as a challenge/opportunity }\end{array}$ & The government hopes to help \\
\hline & $\begin{array}{l}\text { Hope for the business of the } \\
\text { MEA }\end{array}$ & $\begin{array}{l}\text { UMKM develop its products and ready to com- } \\
\text { pete. }\end{array}$ \\
\hline \multirow{11}{*}{$\begin{array}{l}\text { Batik Tulis Gesang Arum } \\
\text { - Owner: Lutfi } \\
\text { Hadiansyah } \\
\text { - Type of batik } \\
\text { merchandise } \\
\text { - Long standing: } 2 \text { years } \\
\text { - Business address: Jl. } \\
\text { East Pagesangan 7, Sby } \\
\text { - Number of employees: } \\
1 \text { person } \\
\text { - Turnover range/month: } \\
\text { Rp } 5 \text { million } \\
\text { - Range of net } \\
\text { profit/month: Rp } 2 \\
\text { million }\end{array}$} & $\begin{array}{l}\text { Marketing strategy that has } \\
\text { been applied }\end{array}$ & Word of mouth and exhibition. \\
\hline & $\begin{array}{l}\text { The current business develop- } \\
\text { ment }\end{array}$ & The business went well. \\
\hline & Business constraints faced & \\
\hline & $\begin{array}{l}\text { The role of Diskoperindag } \\
\text { Surabaya }\end{array}$ & $\begin{array}{l}\text { Difficult to do online promotion because less } \\
\text { master of technology/internet. }\end{array}$ \\
\hline & Trademark development effort & $\begin{array}{l}\text { Very helpful in exhibition, training to increase } \\
\text { knowledge about batik }\end{array}$ \\
\hline & $\begin{array}{l}\text { Understanding and implement- } \\
\text { ing brand identity }\end{array}$ & $\begin{array}{l}\text { Not maximal, only limited to the name of the } \\
\text { brand because of limited capital owned }\end{array}$ \\
\hline & $\begin{array}{l}\text { Understanding and implement- } \\
\text { ing brand image }\end{array}$ & Color and unique batik motif \\
\hline & $\begin{array}{l}\text { Understanding and } \\
\text { implementing brand integrity }\end{array}$ & $\begin{array}{l}\text { Batik fabrics are comfortable to wear and have } \\
\text { a typical nlai fashion Indonesia }\end{array}$ \\
\hline & Understanding of the MEA & Maintaining quality and batik motif \\
\hline & MEA as a challenge/opportunity & Free trade era \\
\hline & $\begin{array}{l}\text { Hope for the business of the } \\
\text { MEA }\end{array}$ & Can be a challenge as well as an opportunity \\
\hline
\end{tabular}


Metta Padmalia \& Dewi M. Immanuel / The Implementation of Marketing 3.0 to MSMEs in Surabaya City / JEE, Vol. 7, No. 1, March 2018, pp. 1-10

\begin{tabular}{|c|c|c|}
\hline \multirow{11}{*}{$\begin{array}{l}\text { - UD. Men's Doubles - } \\
\text { Tree G (Food \& } \\
\text { drink) } \\
\text { - Owner: Suparti } \\
\text { - Merchandise type: } \\
\text { Food \& beverage } \\
\text { - Long standing: } 4 \text { years } \\
\text { - Business address: Jl. } \\
\text { Tanah Merah III G- } \\
\text { 11, Sby. } \\
\text { - Number of employees: } \\
3 \text { persons } \\
\text { - Turnover range/month: } \\
\text { Rp15 million } \\
\text { - Range of net } \\
\text { profit/month: Rp } 6 \\
\text { million }\end{array}$} & $\begin{array}{l}\text { Marketing strategy that has } \\
\text { been applied }\end{array}$ & - Gallery (shop) \\
\hline & $\begin{array}{l}\text { The current business develop- } \\
\text { ment }\end{array}$ & - Direct selling \\
\hline & Business constraints faced & - \\
\hline & $\begin{array}{l}\text { The role of Diskoperindag } \\
\text { Surabaya }\end{array}$ & - Online bukalapak.com \\
\hline & Trademark development effort & $\begin{array}{l}\text { Good development with support from Disko- } \\
\text { perindag, so now more advanced }\end{array}$ \\
\hline & $\begin{array}{l}\text { Understanding and implement- } \\
\text { ing brand identity }\end{array}$ & Promotion is still lacking \\
\hline & $\begin{array}{l}\text { Understanding and implement- } \\
\text { ing brand image }\end{array}$ & Provide training and direction \\
\hline & $\begin{array}{l}\text { Understanding and implement- } \\
\text { ing brand integrity }\end{array}$ & $\begin{array}{l}\text { Currently in the process of administering trade- } \\
\text { mark patents }\end{array}$ \\
\hline & Understanding of the MEA & Name and logo as identity \\
\hline & MEA as a challenge/opportunity & $\begin{array}{l}\text { Brand image is formed in the minds of consu- } \\
\text { mers with many variant choices. }\end{array}$ \\
\hline & $\begin{array}{l}\text { Hope for the business of the } \\
\text { MEA }\end{array}$ & $\begin{array}{l}\text { Brand integrity is maintained by maintaining } \\
\text { the quality and taste quality. }\end{array}$ \\
\hline \multirow{11}{*}{$\begin{array}{l}\text { Embroidery Application } \\
\text { Bag } \\
\text { - Owner: Ruskayanti } \\
\text { - Merchandise type: } \\
\text { Handycraft } \\
\text { - Long standing: } 2 \text { years } \\
\text { - Business address: Jl. } \\
\text { Bogangin 2/3, Sby } \\
\text { - Number of employees: } \\
2 \text { persons } \\
\text { - Turnover/month } \\
\text { range: Rp10 million } \\
\text { - Range of net } \\
\text { profit/month: Rp } 4 \\
\text { million }\end{array}$} & $\begin{array}{l}\text { Marketing strategy that has } \\
\text { been applied }\end{array}$ & - \\
\hline & $\begin{array}{l}\text { The current business develop- } \\
\text { ment }\end{array}$ & - Word of mouth \\
\hline & Business constraints faced & - Store \\
\hline & $\begin{array}{l}\text { The role of Diskoperindag } \\
\text { Surabaya }\end{array}$ & Runs well \\
\hline & Trademark development effort & - Still less promotion and want to export \\
\hline & $\begin{array}{l}\text { Understanding and implement- } \\
\text { ing brand identity }\end{array}$ & - Provide counseling \\
\hline & $\begin{array}{l}\text { Understanding and implement- } \\
\text { ing brand image }\end{array}$ & - Help marketing through exhibitions \\
\hline & $\begin{array}{l}\text { Understanding and implement- } \\
\text { ing brand integrity }\end{array}$ & Changing brand patents \\
\hline & Understanding of the MEA & Do not have brand identity yet \\
\hline & MEA as a challenge/opportunity & \\
\hline & $\begin{array}{l}\text { Hope for the business of the } \\
\text { MEA }\end{array}$ & Do not have a brand image yet \\
\hline \multirow{11}{*}{$\begin{array}{l}\text { Top's Bakery } \\
\text { - Owner: Umi Latifah } \\
\text { - Merchandise type: } \\
\text { Bakery } \\
\text { - Long standing: } 5 \text { th } \\
\text { - Business address: Jl. } \\
\text { Kemlaten XI / 59, } \\
\text { Surabaya } \\
\text { - Number of employees: } \\
3 \text { persons } \\
\text { - Turnover/month } \\
\text { range: } \\
\text { Rp11.000.000,00 } \\
\text { - Range of net } \\
\text { profit/month: } \\
\text { Rp5.000.000,00 }\end{array}$} & $\begin{array}{l}\text { Marketing strategy that has } \\
\text { been applied }\end{array}$ & - Shop \\
\hline & $\begin{array}{l}\text { The current business develop- } \\
\text { ment }\end{array}$ & - Titip sell \\
\hline & Business constraints faced & The business is growing quite well \\
\hline & $\begin{array}{l}\text { The role of Diskoperindag } \\
\text { Surabaya }\end{array}$ & $\begin{array}{l}\text { Names that have not been able to compete with } \\
\text { other bakery }\end{array}$ \\
\hline & Trademark development effort & Provide training \\
\hline & $\begin{array}{l}\text { Understanding and implement- } \\
\text { ing brand identity }\end{array}$ & Create logo and tagline \\
\hline & $\begin{array}{l}\text { Understanding and } \\
\text { implementing brand image }\end{array}$ & Brand use and taste quality \\
\hline & $\begin{array}{l}\text { Understanding and implement- } \\
\text { ing brand integrity }\end{array}$ & Understanding of brand image. \\
\hline & Understanding of the MEA & $\begin{array}{l}\text { The brand image is neat packaging, fast service, } \\
\text { and good quality. }\end{array}$ \\
\hline & MEA as a challenge/opportunity & An understanding of brand integrity. \\
\hline & $\begin{array}{l}\text { Hope for the business of the } \\
\text { MEA }\end{array}$ & $\begin{array}{l}\text { The characteristics developed are good taste } \\
\text { and packaging quality. }\end{array}$ \\
\hline
\end{tabular}

(Primary Data, 2017) 


\section{REFERENCES}

Anonim. 2014. Tantangan dan Peluang UKM Jelang MEA 2015. Majalah SWA Online. Tersedia di: http://swa.co.id/business-research/tantangan-dan-peluang-ukm-jelangmea-2015 [Diakses tanggal 9 September 2015].

Badan Pusat Statistik. 2015. Perkembangan UMKM pada Periode 1997-2012 [Online]. Tersedia di: http://www.bps.go.id/linkTabel Statis/view/id/1322 [Diakses pada tanggal 9 September 2015].

Becherer, R.C., Haynes, P.J. and Fletcher L.P. 2006. Paths to Profitability in Owner-Operated Firms: The Role of Entrepreneurial, Journal of Business and Entrepreneurship, 18 (1): 17-31.

Cooper, D.R. \& Schindler, P.S. 2006. Business Research Methods, 9th Edition. New York: McGraw-Hill Companies, Inc.

Ganie, Y.A. 2012. Kiprah BI Menyongsong MEA 2015. Newsletter Bank Indonesia \#28, 3 (Juli): 3 .

Hadiyati, E. 2015. Marketing and Government Policy on MSMEs in Indonesian: A Theoretical Framework and Empirical Study. International Journal of Business and Management, 10 (2): 128-141.

Hills, G.E., Hultman, C.M., \& Miles, M.P. 2008. The evolution and development of entrepreneurial marketing. Journal of Small Business Management, 46 (1): 99-112.

Ionita D. 2012. Entrepreneurial Marketing: A New Approach for Challenging Times. Journal of Management and Marketing Challenges for the Knowledge Society. 7(1): 131-150.

Kartajaya, H. \& 25 MarkPlus-ers. 2015. Indonesia WOW, Markplus WOW, We are WOW. Jakarta: PT Gramedia Pustaka Utama.
Kementrian Sekretariat Negara RI. 2014. Peluang dan Tantangan Indonesia pada ASEAN Economic Community 2015. Tersedia di: http:/ /www.setneg.go.id/index.php?option = com_content ótask $=$ view $\sigma i d=7911$ [Diakses pada tanggal 9 September 2015].

Kotler, P. \& Armstrong, G. 2003. Dasar-Dasar Pemasaran. Jakarta: Erlangga.

Kotler, P. \& Keller, K.L. 2007. Manajemen Pemasaran. Edisi 12. Jakarta: PT Indeks.

Kotler, P. \& Pfoertsch, W. 2008. B2B brand management. Jakarta: PT Bhuana Ilmu Populer.

Moleong, L.J. 2015. Metode Penelitian Kualitatif. Bandung: Rosdakarya.

Morish, S., Miles, M.P. \& Deacon, J.H. 2010. Entrepreneurial Marketing: Acknowledging the Entrepreneur and Customer-Centric Interrelationship. Journal of Strategic Marketing 18 (4): 303-316.

Morris, M.H., Schindehutte, M. \& LaForge, R.W. 2002. Entrepreneurial Marketing: A construct for Integrating Emerging Entrepreneurship and Marketing Perspectives. Journal of Marketing Theory Practice, 10 (4): 1-19.

Nagel, P.J.F. 2012. “Kecerdasan Kewirausahaan (Entre-Q) untuk Meningkatkan Daya Saing UMKM", Disampaikan dalam Seminar Nasional "Orientasi Kewirausahaan untuk Meningkatkan Daya Saing UMKM”. Diselenggarakan oleh Universitas Jendral Soedirman Purwokerto 21 November 2012. Pandeya, T. 2010. Entrepreneurial Marketing: Prospects and Challenges. BVI R Management Edge 4 (1): 57-65.

Rahmana, Arief. 2008. Usaha Kecil dan Menengah (UKM), Informasi Terdepan tentang Usaha Kecil Menengah, (online), (http://infoukm.wordpress.com, diakses 1 Agustus 2017). 
Metta Padmalia \& Dewi M. Immanuel / The Implementation of Marketing 3.0 to MSMEs in Surabaya City /

JEE, Vol. 7, No. 1, March 2018, pp. 1-10

Reja, U., Manfreda, K.L., Hlebec, V., \& Vehovar, V. 2003. Open-ended vs. Close-ended Questions in Web Questionnaires. Development in Applied Statistics 19: 161-177

Sudaryanto dan Hanim, Anifatul. 2002. Evaluasi Kesiapan UKM Menyongsong Pasar Bebas Asean (AFTA): Analisis Perspektif dan Tinjauan Teoretis. Jurnal Ekonomi Akuntansi dan Manajemen, Vol. 1, No. 2, Desember 2002 .

Stokes, D. 2000. Entrepreneurial marketing: a conceptualization from qualitative research, Qualitative Market Research, 3 (1): 47-54.
Suryana. 2013. Kewirausahaan: Kiat dan Proses Menuju Sukses. Jakarta: Salemba Empat. Tambunan, T.T.H. 2012. "Pasar Bebas ASEAN: Peluang, Tantangan dan Ancaman bagi UMKM Indonesia", Jakarta: Kementrian Koperasi UMKM.

Tyas, A.A.W.P. \& Safitri, V.I. 2014. Penguatan Sektor UMKM sebagai Strategi Menghadapi MEA 2015. Jurnal Ekonomi Volume 5 (1): 42-48. 